\title{
Jenis dan kepadatan tungau debu rumah di Kelurahan Kleak Kecamatan Malalayang Kota Manado
}

\author{
${ }^{1}$ Kandidat Skripsi Fakultas Kedokteran Universitas Sam Ratulangi Manado \\ ${ }^{2}$ Bagian Parasitologi Klinik Fakultas Kedokteran Universitas Sam Ratulangi Manado \\ Email: yohaneshohakay11_127@yahoo.co.id
}

\begin{abstract}
House dust mites in house dust have cosmopolitan distribution. House mites live from eating the remaining cask of human skin scale and grow in a humid environment. Mites are commonly found in beds, carpets, and clothes. This study was aimed to obtain the types and density of dust mites in Kelurahan Kleak Kecamatan Malalayang Manado. This was a descriptive study with a cross sectional study conducted from October to January 2015. Samples of dust were collected from bed, bedroom floor, and sofa in residential houses by using technique simple random sampling. The results showed that there were 5 dust mite samples from Pyroglyphidae, Glycyphagidae, Acaridae, Cheyletidae, and Chortoglyphidae families. Density of house dust mites was 199 mites/13.46 g of dust. The most dominant type of dust mites was the Glycyphagidae family and the highest percentage of its population was in the bedroom floor meanwhile the most dominant population in bed was the Pyroglyphidae family. Conclusion: There were 5 dust mite families- Pyroglyphidae, Glycyphagidae, Acaridae, Cheyletidae, and Chortoglyphidae with the density of 199 mites/13.46 g of dust. The most frequently found mites was the Glycyphagidae family.
\end{abstract}

Keywords: dust mites, types, density

\begin{abstract}
Abstrak: Tungau debu rumah (TDR) terdapat dalam debu rumah dan berdistribusi kosmopolit. Tungau debu hidup dengan memakan sisa skuama kulit manusia dan bertumbuh dalam lingkungan yang lembab. Tungau biasanya ditemukan di tempat tidur, karpet, dan pakaian. Penelitian ini bertujuan untuk mengetahui jenis dan kepadatan TDR yang ditemukan di Kelurahan Kleak Kecamatan Malalayang Kota Manado. Jenis penelitian ialah deskriptif dengan desain potong lintang yang dilakukan selama bulan Oktober sampai Januari 2015. Sampel penelitian yaitu sampel debu yang dikumpulkan dari tempat tidur, lantai kamar tidur, dan sofa yang ada di perumahan penduduk dengan menggunakan teknik simple random sampling. Hasil penelitian mendapatkan 5 jenis TDR dari famili Pyroglyphidae, Glycyphagidae, Acaridae, Cheyletidae, dan Chortoglyphidae. Kepadatan TDR yaitu 199 tungau/13,46 gr debu. Jenis tungau debu yang paling dominan yaitu dari famili Glycyphagidae dengan populasi tertinggi pada lantai kamar tidur sedangkan populasi paling dominan pada tempat tidur yaitu famili Pyroglyphidae. Simpulan: Di Kelurahan Kleak Kecamatan Malalayang Kota Manado terdapat 5 jenis TDR dari famili Pyroglyphidae, Glycyphagidae, Acaridae, Cheyletidae, dan Chortoglyphidae dengan kepadatan TDR yaitu 199 tungau/13,46 gr debu. Jenis TDR yang paling sering ditemukan ialah famili Glycyphagidae
\end{abstract}

Kata kunci: tungau debu rumah, jenis, kepadatan 
Debu rumah merupakan salah satu partikel terkecil yang sering dijumpai dalam kehidupan sehari-hari. ${ }^{1,2}$ Di dalam debu rumah yang sering dibersihkan, terdapat tungau debu yang dikenal sebagai tungau debu rumah (TDR). ${ }^{3}$

Penyebab paling sering dari alergi yang terjadi hampir di seluruh dunia disebabkan oleh tungau debu rumah jenis Dermatophagoides pteronyssinus, Dermatophagoides farinae, dan Blomia tropicalis. Ketiga jenis tungau ini dari famili yang berbeda yaitu famili Glycyphagidae dan Pyroglyphidae dan juga sering menjadi sumber alergen utama. Di daerah tropis dan subtropis, tungau gudang atau yang dikenal Blomia tropicalis merupakan sumber utama alergen dan tungau ini hidup bersama $D$. pteronyssinus. $^{4,5}$

Prevalensi penyakit alergi yang disebabkan TDR berbeda di setiap negara dan peningkatan terjadi hampir di seluruh dunia yaitu sekitar 20\% dari penderita penyakit yang diperantarai oleh antibodi IgE seperti asma, rinitis alergi, dan dermatitis atopi yang berbeda pada setiap negara. ${ }^{6}$ Penelitian yang dilakukan dengan menggunakan kuesioner ISAAC (International Study on Asthma and Allergy in Children) tahun 1995 melaporkan bahwa prevalensi asma sebesar $2,1 \%$, dan pada tahun 2003 meningkat menjadi $5,2 \% .{ }^{7}$ Data dari WHO melaporkan sekitar $50-80 \%$ asma dan rinitis di seluruh dunia disebabkan oleh TDR khususnya Dermatophagoides pteronissinus dan Dermatophagoides farinae.

Tungau debu rumah jenis Dermatophagoides spp. berdistribusi kosmopolit, terdapat dalam debu rumah dan juga dalam sarang burung. Tungau debu jenis ini banyak ditemukan di negaranegara tropis dan subtropis termasuk di Indonesia. ${ }^{3}$ Pada tahun 1964, TDR dari jenis $D$. pteronyssinus dan $D$. farinae diidentifikasi dalam sampel debu rumah dari seluruh dunia, dan dijelaskan pula bahwa TDR dari genus Dermatophagoides merupakan penyebab utama dari reaksi asma. Paparan alergen tungau debu $D$. pteronyssinus dan $D$. farinae merupakan faktor risiko penting untuk sensitisasi alergi, pengembangan asma, dan gejala asma eksaserbasi. ${ }^{8-10}$

Penelitian sebelumnya yang dilakukan di beberapa desa di Manado yaitu di Kelurahan Taas, Kecamatan Tikala dan Titiwungen Selatan, serta Kecamatan Sario di Kota Manado tahun 2013, melaporkan bahwa Acarus spp. sebagai jenis tungau yang paling sering ditemukan. ${ }^{11,12}$ Berdasarkan latar belakang diatas peneliti tertarik untuk melakukan penelitian yang bertujuan untuk mengetahui jenis dan kepadatan TDR pada beberapa habitat dalam bangunan rumah di Kelurahan Kleak Kecamatan Malalayang Kota Manado.

\section{METODE PENELITIAN}

Jenis penelitian ini ialah deskriptif dengan desain potong lintang. Penelitian dilakukan dalam jangka waktu empat bulan yang dilaksanakan pada periode bulan Oktober 2014 - Januari 2015 di Kelurahan Kleak Kecamatan Malalayang Kota Manado menggunakan metode simple random sampling. Sampel penelitian berupa debu rumah yang dikumpulkan dari bangunan rumah penduduk dari lingkungan 1-10 di Kelurahan Kleak Kecamatan Malalayang. Pengambilan debu menggunakan vacuum cleaner berkekuatan 400 watt. Sampel debu kemudian dibawa dan diidentifikasi di Bagian Parasitologi Fakultas Kedokteran Unsrat. Jumlah sampel debu pada bangunan rumah yang diperiksa dihitung menggunakan rumus berikut:

$$
n=\frac{Z \alpha^{2} P Q}{d^{2}}
$$

$\mathrm{n}=$ jumlah sampel minimal

$\mathrm{Z}=$ tingkat kepercayaan (untuk $\mathrm{Z}=90 \%$, nilainya $Z \alpha=1,64)$

$\mathrm{P}=$ proporsi sampel debu yang positif terdapat tungau

Pada penelitian sebelumnya yang dilakukan di Kota Manado, proporsi sampel debu yang positif terdapat tungau 
sekitar $90 \%(0,9)$

$\mathrm{Q}=1-\mathrm{P}=0.1$

$\mathrm{D}=$ limit dari error atau presisi absolut

$$
n=\frac{(1.64)^{2} 0.9(0.1)}{(0.05)^{2}}=96
$$

\section{HASIL PENELITIAN DAN BAHASAN}

Kelurahan Kleak Kecamatan Malalayang memiliki luas wilayah mencapai 188,89 ha dengan 457 bangunan rumah 457 yang terbagi atas 10 lingkungan. Kelurahan Kleak memiliki potensi unggulan di bidang sumber daya alam yang menghasilkan produk unggulan seperti pengolahan dan pembuatan tahu tempe, pembuatan produk olahan kayu manis, dan merica Jawa. ${ }^{13}$

Tabel 1 menunjukkan bahwa 89 $(92,7 \%)$ dari 96 sampel debu yang diambil dinyatakan positif tungau sedangkan 7 sampel yang tersisa dinyatakan negatif. Hal ini mungkin disebabkan saat dilakukan pengambilan sampel debu, ditemukan rumah dalam kondisi jarang dibersihkan, dan kondisi cuaca pada saat itu periode bulan Oktober-Desember (musim penghujan) dengan kelembaban meningkat yang dapat menjadi faktor pencetus pertumbuhan dan perkembangbiakan tungau. $^{14-16}$

Tabel 1. Presentase sampel positif dan negatif tungau debu

\begin{tabular}{lcc}
\hline \multicolumn{1}{c}{ Hasil } & Jumlah & \% \\
\hline Tungau (-) & 7 & 7,2 \\
Tungau (+) & 89 & 92,7 \\
Total sampel & 96 & 100,0 \\
\hline
\end{tabular}

Tabel 2 menunjukkan bahwa jenis tungau yang ditemukan dan diidentifikasi menurut kunci $\mathrm{Mj}$. Collof et al. meliputi famili Glycyphagidae, Pyroglyphidae, Acaridae, Cheylitidae, dan Chortoglyphidae. Jenis tungau yang paling banyak ditemukan yaitu famili Glycyphagidae berjumlah 74 tungau sednagkan yang paling sedikit ialah famili
Cheylitidae dan Chortoglyphidae.

Penelitian yang dilakukan Olsson dan van Hage-Hamsten ${ }^{17}$ melaporkan bahwa tungau debu dari famili Glycyphagidae banyak terdapat di daerah dengan lingkungan pertanian. Pada penelitian ini terdapat 40 tungau yang tidak teridentifikasi. Pada Tabel 2 juga terlihat jenis tungau debu yang memiliki populasi ke dua dominan yaitu famili Pyroglyphidae dengan jumlah 67 tungau. Penelitian lain yang dilakukan di Israel melaporkan jenis tungau debu yang paling lazim ditemukan di rumah di Israel yaitu $D$. pteronyssinus dari famili Pyroglyphidae dengan persentase dalam debu rumah antara $75 \%$ dan $92 \% .^{18}$

Tabel 2. Perbandingan jenis dan jumlah tungau debu pada 3 habitat

\begin{tabular}{lcccc}
\hline \multicolumn{1}{c}{ Famili } & $\begin{array}{c}\text { Tempat } \\
\text { tidur }\end{array}$ & $\begin{array}{c}\text { Lantai } \\
\text { kamar } \\
\text { tidur }\end{array}$ & Sofa & Jumlah \\
\hline Pyroglyphidae & 24 & 22 & 21 & 67 \\
Glycyphagidae & 17 & 33 & 24 & 74 \\
Acaridae & 5 & 6 & 3 & 14 \\
Cheylitidae & - & - & 3 & 3 \\
Chortoglyphidae & 1 & - & - & 1 \\
Tidak & 15 & 15 & 10 & 40 \\
teridentifikasi & & & & 199 \\
\hline Jumlah & & & & \\
\hline
\end{tabular}

Tabel 3 menunjukkan perbedaan jumlah tungau debu yang diperoleh dari 3 habitat. Kepadatan tungau debu paling banyak yaitu di lantai kamar tidur dengan jumlah 74 tungau, di sofa 67 tungau, di tempat tidur 59 tungau. Hasil keseluruhan menunjukan bahwa kepadatan tungau debu di Kelurahan Kleak yaitu 199 tungau/13,46 gr debu.

Penelitian lain yang dilakukan di Kota Turki menunjukkan dari 72 sampel debu, jumlah tungau yang ditemukan dalam 1 gram debu bervariasi dari 25 sampai 2,740 khususnya dari famili Pyroglyphidae dan famili Glycyphagidae. ${ }^{19}$ Penelitian yang dilakukan di North Western Polandia dengan mengambil sampel debu pada habitat tempat tidur di apartemen di Polandia melaporkan bahwa lebih dari 
Hohakay, Warongan, Bernadus: Jenis dan kepadatan tungau debu rumah ...

setengah populasi tungau dalam debu ialah dari famili Pyroglyphidae dan sisanya dari

famili lain yaitu Chortoglyphidae dan Acaridae. ${ }^{20}$

Tabel 3. Total kepadatan tungau debu berdasarkan berat debu secara keseluruhan

\begin{tabular}{|c|c|c|c|c|c|c|}
\hline \multirow{2}{*}{$\begin{array}{l}\text { No. Rumah R1- } \\
\text { R32 }\end{array}$} & \multicolumn{2}{|c|}{ Tempat tidur } & \multicolumn{2}{|c|}{ Lantai kamar tidur } & \multicolumn{2}{|c|}{ Sofa } \\
\hline & $\begin{array}{l}\text { Berat } \\
\text { debu }\end{array}$ & $\begin{array}{l}\text { Jumlah } \\
\text { tungau }\end{array}$ & $\begin{array}{l}\text { Berat } \\
\text { debu }\end{array}$ & $\begin{array}{l}\text { Jumlah } \\
\text { tungau }\end{array}$ & $\begin{array}{l}\text { Berat } \\
\text { debu }\end{array}$ & $\begin{array}{l}\text { Jumlah } \\
\text { tungau }\end{array}$ \\
\hline Total & 4,58 & 61 & 4,76 & 74 & 4,12 & 64 \\
\hline $\begin{array}{l}\text { Kepadatan tungau } \\
\text { (tungau/gr debu) }\end{array}$ & \multirow{3}{*}{\multicolumn{2}{|c|}{13,31}} & \multicolumn{2}{|c|}{15,54} & \multirow{3}{*}{\multicolumn{2}{|c|}{15,53}} \\
\hline Berat total debu & & & & $13,46 \mathrm{~g}$ & & \\
\hline Total tungau & & & & 199 & & \\
\hline
\end{tabular}

\section{SIMPULAN}

Dari hasil penelitian di Kelurahan Kleak didapatkan lima jenis TDR dari famili Pyroglyphidae, Glycyphagidae, Acaridae, Cheyletidae, dan Chortoglyphidae dengan kepadatan TDR yaitu 199 tungau/13,46 gr debu. Jenis TDR yang paling sering ditemukan ialah famili Glycyphagidae

Tingkat kepadatan tungau debu tertinggi yaitu pada lantai kamar tidur dan terendah pada tempat tidur.

\section{DAFTAR PUSTAKA}

1. Faiza A. Hubungan antara lama penggunaan kasur kapuk dengan jumlah populasi tungau debu rumah di perumahan PJKA Kelurahan Randusari Semarang. Jawa Tengah. Semarang: Universitas Diponegoro; 2006.

2. Yudopranoto K. Perbandingan populasi tungau debu rumah pada kasur kapuk dan non-kapuk di perumahan PJKA Kelurahan Randusari Semarang Selatan Jawa Tengah. Semarang: Universitas Diponegoro; 2006.

3. Natadisastra D, Agoes R. Parasitologi Kedokteran Ditinjau dari Organ Tubuh yang Diserang. Jakarta: EGC, 2009.

4. Steinman H. Dermatophagoides pteronyssinus. [cited 2014 Oct 14]. Available from: http://www. phadia.com/da/Products/Allergytesting-products/ImmunoCAPAllergen-Information/Mites/ Allergens/Dermatophagoidespteronyssinus/

5. Valmonte G, Cauyan G, Ramos J. IgE cross-reactivity between house dust mite alergens and Ascaris lumbricoides antigens. Asia Pacific Allergy. 2011;2:35-44.

6. Wistiani, Notoatmojo $H$. Hubungan pajanan alergen terhadap kejadian alergi pada anak. Sari Pediatri. 2011;13(3):188.

7. Rengganis I. Diagnosis dan tatalaksana Asma Bronkial. Maj Kedok Indon. 2008;58(11):450-1.

8. Spieksma FT. Biological aspects of the house dust mite (Dermatophagoides pteronyssinus) in relation to house dust atopy. Clin Exp Immunol. 1970;6(1):61-70.

9. Pope AM, Patterson R, Burge H. Indoor alergens. Assessing and Controlling Adverse Health Effects. Washington: National Academy Press, 1993.

10. Wharton GW. House dust mites. J Med Entom. 1976;12:577-621.

11. Walangare $\mathbf{K}$. Tungau debu rumah di Kelurahan Taas Kecamatan Tikala Kota Manado. eBm. 2013;1(1).

12. Worang I, Sorisi A, Pijoh VD. Tungau debu rumah yang ditemukan di Kelurahan Titiwungen Selatan Kecamatan Sario Kota Manado. eBm.2014;2(1).

13. Profil Kelurahan Kleak Kecamatan Malalayang Tahun 2012.

14. Dust allergy. 2014 [cited 2014 Oct 214] Available from: www.acaai.org/ allergist/allergies/types/dust-allergyinformation/pages/default.aspx

15. Colloff M. Dust Mite. E-book. 1958; p.155.

16. Sutanto I, Ismid Is, Sjarifuddin PK, Sungkar S. Parasitologi Kedokteran (4th ed). Jakarta: FKUI, 2011; p. 288. 
17. Olsson S, van Hage-Hamsten M. Alergens from house dust and storage mites: similarities and differences, with emphasis on the storage mite Lepidoglyphus destructor. Clin Exp Allergy. 2000;30:912-19.

18. Mumcuoglu KY, Gat Z, Horowitz T, Miller J, Bar-Tana R, Ben-Zvi A, et al. Abundance of house dust mites in relation to climate in contrasting agricultural settlements in Israel. Med Vet Entomol. 1999;13:252-54.
19. Aykut M, Erman OK, Dogan S. Seasonal Changes of House Dust Mites Population in Bitlis and Mus Province of Turkey. Turkiye Parazitol Derg. 2013;37:115-6.

20. Bogacka K, Kalisinska E, Henszel L, Kuzna G. Seasonal dynamics of house dust mites in dust samples collected from sleeping places in North-Western Poland. Zoonoses and Public Health. 2012;59:11. 